\title{
The Use of Tree-Related Microhabitats as Forest Biodiversity Indicators and to Guide Integrated Forest Management
}

\author{
Thomas Asbeck $^{1}$ (D) $\cdot$ Josef Großmann ${ }^{1,2}$ (D) Yoan Paillet $^{3}$ (D) N Nathalie Winiger ${ }^{4} \cdot$ Jürgen Bauhus $^{1}$
}

Accepted: 28 December 2020 / Published online: 18 January 2021

(C) The Author(s) 2021

\begin{abstract}
Purpose of the Review The concept of tree-related microhabitats (TreMs) is an approach to assess and manage multi-taxon species richness in forest ecosystems. Owing to their provision of special habitat features, TreMs are of special interest as a surrogate biodiversity indicator. In particular, in retention forestry, TreMs have gained attention over the past decade as a selection criterion for retained structural elements such as habitat trees. This review seeks to (a) address the suitability of TreMs as biodiversity indicator in the context of retention forestry, (b) summarize drivers of TreM occurrence and the status quo of the implementation of TreM-based retention concepts in forest management, and (c) discuss current and future challenges to the use of TreMs as biodiversity indicator.

Recent Findings The TreM concept originated in Europe where it is now increasingly implemented. Most studies of the quantity, quality, and diversity of TreMs are focused on tree species from this region, although it is increasingly applied in other contexts. In addition to tree species, tree dimensions and live status have been identified as the main drivers of TreM occurrence. One major remaining research challenge is to verify relationships between the occurrence and abundance of forest-dwelling species from different taxonomic groups and TreMs to improve the evidence basis of this concept and thus increase its integration in forest conservation approaches.

Summary TreMs are not the "silver bullet" indicator to quantify biodiversity of forest dwelling species, but they provide an important tool for forest managers to guide the selection of habitat trees for the conservation of the associated biodiversity.
\end{abstract}

Keywords Retention forestry $\cdot$ Habitat trees $\cdot$ Sustainability indicator $\cdot$ Drivers of tree-related microhabitats

\section{Introduction}

Initial studies of tree-related microhabitats (TreMs) were conducted with individual typologies and definitions to capture the variation of microhabitats and to classify them according to different habitat functions [1-3]. Nowadays, the most common definition for a tree-related microhabitat (TreM) is "a distinct, well delineated structure occurring on living or standing dead trees that constitutes a particular and essential substrate or life site for species or species communities during at

This article is part of the Topical Collection on Ecological Function

Thomas Asbeck

thomas.asbeck@waldbau.uni-freiburg.de

Josef Großmann

josef.grossmann@waldbau.uni-freiburg.de

Yoan Paillet

yoan.paillet@inrae.fr

Nathalie Winiger

nathalie.winiger@wildlife.uni-freiburg.de

Jürgen Bauhus

juergen.bauhus@waldbau.uni-freiburg.de
University of Freiburg, Tennenbacherstr, 4, 79106 Freiburg, Germany

2 Department of Forest Conservation, Forest Research Institute Baden-Württemberg, Wonnhaldestr. 4, 79100 Freiburg, Germany

3 University Grenoble-Alpes, INRAE, Lessem, 2 rue de la Papeterie, BP76, 38402 Saint-Martin-d'Hères, France

4 Wildlife Ecology and Management, Tennenbacherstr. 4, 79085 Freiburg, Germany 
least a part of their life cycle to develop, feed, shelter or breed" [4.•]. This definition was established during the course of an expert working group led by the European Forest Institute (EFI), which resulted in first recommendations for the application of a standardized TreM concept [5]. The hierarchical TreM typology for temperate and Mediterranean forests that was published by Larrieu et al. [4••] distinguishes 15 groups of TreMs in the following seven forms:

- Cavities: woodpecker breeding cavities, rot holes, concavities, insect galleries, and bore holes

- Tree injuries and exposed wood: exposed sapwood and/or exposed heartwood;

- Crown deadwood in different forms

- Excrescences: twig tangles (witches broom), cankers, and burrs

- Fruiting bodies of saproxylic fungi and slime molds: perennial and ephemeral fungi fruiting bodies

- Epiphytic, epixylic, and parasitic structures: epiphytic crypto- and phanerogams, nests of vertebrates and invertebrates, micro-soil (i.e. resulting from decay of lichens, mosses or leaf litter in either thick, old bark, or on horizontal limbs and forks for instance)

- Fresh exudates such as sap run and heavy resinosis

As reflected in the definition, the underlying concept is that TreMs represent a habitat component of different forestdwelling species and thus they may indicate their potential presence. A variety of species from different taxonomic groups have been linked to the different TreMs used in the hierarchical typology. These include invertebrates such as insects, arachnids, and gastropods as well as vertebrates such as birds, rodents, bats, and carnivores [4••].

Most information on TreMs stems from literature that originated in the context of retention forestry $[6,7]$. Retention forestry belongs to a set of integrative biodiversity conservation strategies [8] and focuses on the provisioning of particular, biodiversity-relevant, often old-growth structures that are otherwise lacking or reduced in forests managed for wood production $[9,10]$. These structures are supposed to provide a life-boating function for the associated species or act as stepping stones between larger retention patches, forest reserves, or primary forest remnants and thus increase the connectivity in managed forests $[11,12]$ and even the full habitat for a viable population for very specific taxonomic groups. Apart from coarse woody debris, living and standing dead trees have been central to most of these retention concepts within Europe and elsewhere [13, 14]. These elements are mostly referred to as habitat trees (or veteran, senescent, or wildlife trees). Habitat trees are broadly defined as large, old, living, or dead microhabitat-bearing trees that are or could become more important to biodiversity than the average tree in a managed forest [15]. The idea of habitat tree conservation has a long tradition in temperate European forests [16], but in earlier times, it was not as systematically applied as is the case now under integrative approaches in forest management such as retention forestry $[13 \bullet \cdot]$. TreMs are of special interest in continuous-cover forestry, where they are used as criteria to select habitat trees for retention [13, 17]. While TreMs have so far been used mostly in this context, they can equally well be used in other types of forest management as well as the management of urban parks and street trees [18]. In addition, they are useful for communication of biodiversity focused forest management approaches [19]. Against this background, this review seeks to:

- Address the function of TreMs as biodiversity indicators in the context of integrative forest management approaches such as retention forestry

- Synthesize drivers of TreM occurrence and the status quo of implementations of TreM concepts in forest management

- Discuss current and future challenges of TreMs as biodiversity indicators

\section{The Potential of TreMs as Biodiversity Indicators}

There is a large and growing body of literature on different types of indicators of forest biodiversity [20-26]. Various attempts have been made to develop indicators of forest biodiversity for large gradients of spatial and temporal scales. These range from the use of single keystone or flagship species to faunal [27] or structural surrogates (e.g., deadwood [22, 28]). An indicator is a measure of a quantity or a phenomenon that is easier to assess than its target (viz., the indicandum). The use of an indicator should also bring more information than the raw measure of the indicandum only. The validation of biodiversity (or environmental) indicators in ecological studies strongly focuses on the correlation between the indicator and its indicandum: for a given indicator to be validated, the correlation with its indicandum should be strong and significant [29]. However, the thresholds for a correlation to be considered "strong" for this purpose are rarely defined, while statistical significance mostly depends on the sample size analyzed. Therefore, it seems that this validation process should rely on a wider set of criteria, as commonly applied in political and human sciences [30]. From the broader point of view of social sciences, and particularly of political sciences, indicators are frontier objects that allow communication between science, policy, and society, and the assessment of their usefulness should be based on many more criteria than only the correlation with the indicandum [31•]. While correlation and causality rely on ecological theory, mostly on different conceptual approaches of the relationship between species and their habitat 
(e.g., niche theory, habitat amount and heterogeneity hypotheses [32]), broader views of indicator usefulness include social acceptance, policy relevance, and comprehensibility (see Table 1 in [30] for an overview).

The Organization for Economic Co-operation and Development (OECD), which has a long history of developing and using environmental indicators for reporting purposes, suggests that "indicators should be assessed/evaluated according to their (i) policy relevance, (ii) analytical soundness, and (iii) measurability. The [...] ideal indicator for measuring progress should be [...] policy-relevant and meaningful, biodiversity relevant, scientifically sound, accepted by a broad public, lend itself to affordable monitoring and modelling, and be sensitive enough to detect changes in systems within timeframes and on scales relevant to decision-making" [31•]. Indicators are similarly defined in the criteria and indicator processes that have been initiated to support sustainable forest management around the globe since the United Nations Conference on Environment and Development (UNCED) of Rio 1992 (e.g. [33]). In this regard, one might ask whether TreMs, when used as biodiversity indicator, meet these criteria proposed by the OECD [31•]. Among others, the Pressure-State-Response (PSR) framework used by the OECD has received some attention in forest and biodiversity science to address various types of questions [21, 34, 35]. The PSR framework has been developed to provide information to respective users in a causal way by differentiating between causes (pressure) of changes in biodiversity, effects on biodiversity (state) caused by the specific pressure, and societal responses to assess and remedy the human impacts on nature [35]. As mentioned above, there are other frameworks than the PSR that use biodiversity indicators for sustainability assessments. However the PSR framework exemplifies the relevance of TreMs as indicators of the state of forest biodiversity. In the context of integrative nature conservation practices such as retention forestry, TreMs could be used as meaningful structural indicators for the state of biodiversity at the stand scale. In this context, one major pressure on biodiversity in forests may be expressed as the proportion of forest biomass productivity that is appropriated (harvested) for human consumption [36, 37]. The harvesting of forest biomass is associated with the direct loss of habitats and the removal of energy and nutrients to develop extensive food chains/networks, which halts the development of old-growth habitat. Related to this pressure, TreMs could indicate the state of the diversity of forest dwelling species by describing the status quo of the provisioning of suitable habitats in managed and unmanaged forests $[17,38-40]$. TreMs could be used to quantify the biodiversity at a structural, indirect level [41, 42]. It has been shown that TreMs are sensitive to the above pressure with lower abundance and diversity in managed than in mediumor long-term unmanaged forests. TreMs could be a useful and convenient indicator because their assessment, like that of dead wood, could be readily integrated into many types of terrestrial forest inventories, ranging in scale from the ownership to the national level (e.g., [28, 43]). For example, in forest inventories that already quantify the number of habitat trees, it would be a logical next step to quantify TreMs (e.g., [13••]). Since there is, owing to the very high costs that would be involved, no routine inventory of a wide range of forestdwelling species across the forest landscape, the indirect indication of potential habitat could provide this information efficiently across forest types, ownerships, etc. A related societal response to this pressure and an undesired state in the provision of habitats could be indicated by the proportion of forestland that is in strict reserves or managed with a retention forestry approach, which is already required in different certification systems $[13,44]$. Retention forestry aiming at maintaining forest organisms, structures, and connectivity to support biodiversity and ecosystem functioning beyond harvesting interventions would be closely related to the above pressure and state indicators. Following an adaptive management concept, TreMs could then offer a way to quantify habitats provided by retention forestry and thus assess the success of the retention forestry approach.

In addition to the mentioned PSR framework, in an earlier meta-analysis on types of biodiversity indicators, TreMs were classified as "temporal and other structural indicators" which are especially relevant at the stand scale [20]. Temporal indicators refer to indicators that are able to quantify shifts in the state of the biodiversity in a specific ecosystem over time. With regard to international sustainable forest management processes such as Forest Europe, TreMs could potentially be used as an indicator for the criterion biodiversity, where currently "Deadwood" and "Naturalness", among others, already serve as quantitative indicators [45]. To be used as biodiversity indicator in these international processes that promote sustainable forest management, TreMs would have to be routinely quantified in national forest inventories of the participating countries.

In contrast to quantifying the occurrence or abundance of single or multiple species, which are difficult and/or expensive to assess at the stand scale, TreMs offer an applicable indicator of biodiversity at the stand scale. In the context of measurability, cost is an important property, which is relatively low compared with more labor and time-consuming inventories of a wide range of different species that are additionally often bound to specific times (e.g., breeding/non-breeding season) of the year. This does not necessarily hold true for all species groups, but certainly regarding the multi-taxon level information that TreM inventories provide. TreM inventories can be carried out throughout every season, although leafless and snow-free periods are preferred. This could especially be relevant, when TreM inventories are included in already existing forest inventories. This applicability is an important aspect for a forest biodiversity indicator. An illustration of the lack of 
Table 1 Examples of the use of tree-related microhabitats (TreMs) as selection criteria for retention elements in managed forests as stated in management concepts of publicly owned forests at regional and national levels in four countries of Central Europe as well as certification schemes for Germany

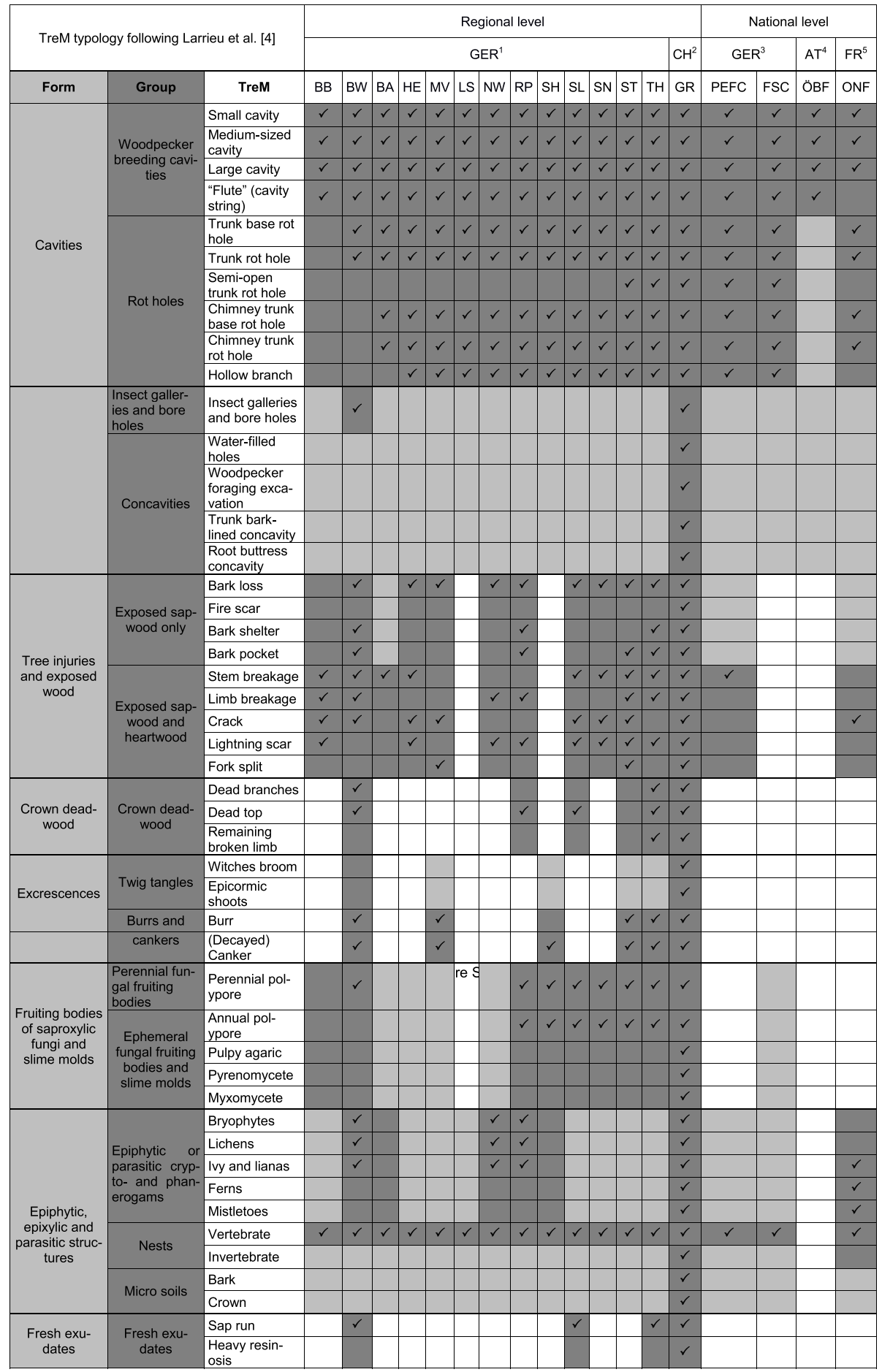

Light gray indicates a consideration at the level of TreM form, dark gray refers to TreMgroups and $\checkmark$ " indicates the mentioning of the specific TreM in the concept following the typology of Larrieu et al. [4]. White or empty cells indicate no consideration of TreMs in the respective concept.

${ }^{1}$ GER = Germany; BB = Federal state (FS) Brandenburg; BW = FS Baden-Württemberg; BA = FS Bavaria, HE = FS Hesse; MV = FS MecklenburgVorpommern; LS = FS Lower Saxony; NW = FS North Rhine-Westphalia; RP = FS Rhineland-Palatinate; SH = FS Schleswig-Holstein; SL = FS Saarland; SN = FS Saxony; ST = FS Saxony-Anhalt; TH = FS Thuringia $;{ }^{2} \mathrm{CH}=$ Switzerland; GR $=$ Canton Graubünden; ${ }^{3} \mathrm{PEFC}=\mathrm{Program}$ for the Endorsement of Forest Certification Schemes; FSC = Forest stewardship council; ${ }^{4} \mathrm{AT}=$ Austria; ÖBF $=$ Austrian national forest service; ${ }^{5} \mathrm{FR}=\mathrm{France}$; $\mathrm{ONF}=$ French national forest service. For specific references to the mentioned guidelines see SI 
measurability of other indicators at the stand scale are certain insect indicator species, which often have much finer requirements on spatial scales $[46,47]$ compared, for instance, with indicator species of birds [23] that require usually larger sampling areas. Therefore, inventories of TreMs, and more generally structural attributes, offer an interesting complementary alternative.

\section{Determinants of Tree-Related Microhabitat Occurrence}

TreMs, in varying forms and definitions, have been investigated in forests for more than a decade, and we now have an increasingly sound knowledge basis that can be synthesized $[1,3,18,48]$. The underlying importance of analyzing driving factors of TreM occurrence was pointed out in the definition by the OECD, which states that indicators should be scientifically sound and sufficiently sensitive to detect changes between systems at relevant scales [31•]. Therefore, understanding drivers of this potential biodiversity indicator delivers the basis to assess its usefulness and to identify contexts in which TreMs could be a valuable tool. The research on TreMs has had a strong regional focus in Central-Europe and the Mediterranean, notably the typology of TreMs [1, 3, 17, 39, 48-50]. Therefore, most of the studies are related to TreMs on tree species that occur in these regions, mostly European beech (Fagus sylvatica L.), silver fir (Abies alba Mill.), Norway Spruce (Picea abies L.), as well as different European oak species (Quercus spp.) [1-3, 17, 49, 51]. There are fewer studies on tree species such as Douglas fir (Pseudotsuga menziesii (Mirb.) Franco) or Oriental beech (Fagus orientalis Lipsky (Fo)) from outside Europe [52-56]. All these studies have in common that tree species is a determining factor of TreM abundance and richness. Commonly broadleaf trees or forest types that include shares of broadleaves provide more TreMs than coniferous ones [17, 49].

A second important determinant of TreM occurrence is tree dimension. In this regard, diameter at breast height (DBH) has proven to be a strong and significant driver of TreM occurrence in all studies that considered this common mensurational variable [e.g., 15,34,39]. In general, large trees support a greater abundance and richness of TreMs across all tree species [51, 52, 57, 58]. It is not fully understood whether tree species or dimension is more decisive, but both are usually the two most important drivers of TreM occurrence. It should be noted that there are, to the best of our knowledge, so far just one modeling study [59] and one study based on observational data [60] which have made the effort to analyze the relationship between tree age and TreMs. Other studies understood tree dimension as an indirect measure of tree age [17•], although this relationship between diameter and age can be extremely variable, in particular in uneven-aged forests (e.g., [61]). Tree dimension is also related to the crown position class of trees, typically declining from dominant, to co-dominant, intermediate, and suppressed trees. This crown position class might have some effect on TreMs as well, since trees of different crown classes have undergone divergent developments and are exposed to different processes with relevance to TreM formation; e.g., wind breakage of large limbs might be greater in trees in the top canopy layer [62]. There have been only a few studies that have considered crown class, but it seems that mostly large, dominant trees in the upper canopy layer provide more TreMs than suppressed ones [58]. The relatively recent establishment of the TreM concept as well as the time required for trees to form TreMs did not allow the establishment of reliable time series based on longitudinal observations of their development on the same trees at this stage.

The third major determinant of TreMs is the live status of trees $[49,51,58]$. In most cases, standing dead trees or snags provide more TreMs than living trees of comparable dimensions $[49,57]$. For instance, the TreM groups of woodpecker feeding holes as well as saproxylic fungi have been found more frequently on snags $[49,51]$.

Lastly, the frequently assessed influence of forest management has been considered a crucial determinant for the occurrence of TreMs [17, 39, 53, 57]. However, the relationship of management types and TreM richness is not trivial to scrutinize. The management influence varies with the silvicultural systems applied, as harvesting might on the one side remove habitat trees and on the other side damage trees and thus trigger the developments of new TreMs such as exposed heart wood or broken limbs. In central Europe, for instance, continuous cover forestry, and more particularly close-to-nature forest management, is often practiced [63, 64]. In this approach a selection of habitat trees with a focus on small structures such as TreMs throughout the whole landscape is feasible at small spatial scales, whereas in even-aged forestry with larger management units, this is likely more difficult $[13,65]$. Owing to the different retention approaches in forest management, such as simply maintaining certain basal areas or volumes as practiced in other parts of the world, for instance, in Canada [53•], clear patterns of TreMs in response to management are difficult to establish. In remnants of clearcuts, TreMs were almost absent, whereas shelterwood treatments maintained TreM numbers similar to uncut control plots in mixed hardwoods [53•]. In Europe, in contrast, there were no differences in TreMs between uneven-aged and even-aged stands of the same forest type [17•], whereas other factors such as the time since last harvest and the difference in number of snags between managed and unmanaged stands were more important [57]. In addition, there is so far little information from oldgrowth or primary forests to facilitate comparisons with managed forests. However two studies have provided first reference numbers of TreMs for primary forests of European beech and Oriental beech $[38,52]$. 


\section{Implementation of Tree-Related Microhabitats as Biodiversity Indicators}

The relevance of TreMs as biodiversity indicators is underpinned by the fact that the TreM concept has been widely adopted in integrative conservation concepts in temperate forests of central Europe. For example, a number of institutions, federal states, as well as certification schemes (PEFC, FSC) in Germany, Austria, Switzerland, and France use TreMs as selection criteria for habitat trees (Table 1; [66]), although they often are referred to with other terms. When compiling information for Table 1, we did not attempt to provide a full coverage of locally implemented concepts, but included recommendations that were implemented at least at a regional level (Table 1). In addition to guidelines implemented at regional levels (e.g., federal states in Germany), national certification standards suggest the use of TreMs for the selection of retention elements (Table 1). The integrative conservation concepts listed here evolved from the need for a systematic and precautionary consideration of legally protected habitats in forest management, which include large vertebrate nests or woodpecker cavities $[67,68]$. These concepts might as well include microhabitats that are essential for other organisms (mainly invertebrates) [4••]. Most recommendations are valid for state forests, and in some cases other public forests, but do not necessarily apply to private forests. These concepts often focus on TreM groups or single TreMs as guidance for forest managers to indicate trees that have a higher than average natural value and may be setaside for retention purposes (Table 1). If a certain tree bears a TreM that is recognized as a (legally) protected microhabitat, it has to be retained as habitat tree. TreM-bearing trees can be set aside individually [65] or in the form of small retention patches, so called habitat tree groups or set-aside islands. Besides woodpecker cavities, rot holes, and large vertebrate nests, which are a mandatory selection criteria in all of the mentioned guidelines, injuries exposing sap- or heartwood as well as fruiting bodies of saproxylic fungi are frequently considered as TreMs as well, to qualify individuals as habitat trees (Table 1). Crown deadwood and excrescences, such as burrs and canker or exudates, are rarely listed as criteria for selecting habitat trees. However, more recently approved or updated management guidelines consider a broader range or the full spectrum of the current TreM typology (e.g., in the German state of BadenWürttemberg or the Swiss canton Graubünden; Table 1). In addition to the presence of TreMs, trees are commonly selected for retention based on exceptional dimensions or bizarre shapes (Table SI 1). Also tree species is often an important selection criterion when the aim is to conserve rare tree species or those with high species-specific dependent biodiversity [40]. Most commonly, the retention concepts are applied in older forest stands entering the harvesting phase and aim at maintaining five to ten habitat trees per hectare. Formerly used, partly anecdotic, descriptors to identify habitat trees referring to "ancient trees," "senescent trees," or "veteran trees" are becoming more commonly objectively described with the help of the TreM typology.

\section{Current and Future Challenges of Tree-Related Microhabitats as Biodiversity Indicators}

From an ecological point of view of, the validation of TreMs as biodiversity indicators crucially relies on the improvement of our understanding of their link with actual species diversity and abundance. While numerous studies (listed in [4, 69]) have empirically established the dependence of some species and groups to certain microhabitat types, they usually do so without a quantification of the link, frequently lacking evidence for the actual strength of the relationship. In addition, most of the correlations between the occurrence of certain species, species richness, or diversity and microhabitat metrics recently observed remain relatively noisy and are moderately associated [41, 42, 48, 70]. Such relationships with overall richness or specific types of TreMs based on observational studies at the stand (plot) level have been reported so far for birds, bats, and to a lesser extent (saproxylic) insects [41, 42]. The noise in these relationships is partially caused by the fact that forest-dwelling species included do not directly rely on any of the inventoried TreMs for their habitat requirements or the habitat range does not match the spatial scale at which TreMs have been inventoried. For example, some studies have ignored TreMs on dead wood [17, 52]. This could have a significant impact on the result as not all species rely exclusively on TreMs borne by living trees and more TreMs occur on snags compared with living trees [57]. Still, such relatively low levels of correlation are not uncommon to other popular structural biodiversity indicators such as deadwood [22]. Other variations in biodiversity that structural indicators can typically not capture is the spatial and temporal context that strongly influences species richness of the associated taxa; this includes site conditions such as climate or distance to source populations as well as management history [12, 64].

These results of the correlations between TreMs and species either concern indices based on microhabitat lists (such as microhabitat diversity [41・•]) or individual microhabitats (e.g., conks of fungi and cavities [70]), but they all have in common observational methods at the stand (plot) scale that do not target specific TreMs. Such methods have the advantage of covering a large range of TreM types and taxonomic groups and, in the latter case, are reputed to correctly assess the stand or plot-related richness at community level (e.g., window traps for beetles [71], point counts for birds [23]). However, the cumulative effects of detection errors for both TreMs [72] and the associated taxonomic groups, and more generally the difficulties to approximate true abundance 
levels, may partly explain the noise in correlations, next to the spatial-temporal factors. In addition, sampling species diversity at a plot level may overlook species specific to certain TreMs, especially smaller invertebrates or rare species [73]. Such sampling methods are also limited for assessing robust causal and functional links between specific microhabitats and species richness of the assessed taxonomic groups, but are a crucial step in the validation of TreMs as an indicator of overall species richness.

Some ways to improve TreM inventories have been suggested $[4,72,74]$, for instance conducting inventories with standardized recording protocols and teams of more than one observer, yet their efficiency has not been tested rigorously. To monitor or prevent observer bias, repeated measurements or comparative studies of TreMs with standardized protocols and the same teams would be necessary [72]. Other approaches have focused on the use of remote sensing techniques to identify TreMs either at the treelevel directly $[74,75]$ or to predict the occurrence of trees bearing TreMs from stand characteristics [76 $]$ both from terrestrial laser scanning as well as airborne inventories. However, to detect the full range of TreMs from these inventories or to predict the location of habitat trees accurately for forest management remains a future challenge.

Similarly, a first step towards the improvement of standardized sampling of taxonomic groups would be to combine different sampling methods targeting taxa directly at the microhabitat level rather than relying on correlational studies. For example, some studies correlating microhabitat indices with saproxylic beetle diversity used only interception traps $[71,77]$. A broader view of the saproxylic insect community as well as better estimates of abundance in direct relation to TreMs could be obtained through the combined use of different sampling methods such as pitfall traps, interception traps, and malaise tents at the entrance of cavities, for instance [e.g., 70]. Another approach would be targeted sampling of specific species or their DNA in relation in specific types of TreMs (e.g., [78]). For particular groups of vertebrates, the combination of automatic acoustic methods, camera traps, and classical point counts may lead to better community estimates [79]. Finally, relatively new approaches involving genetic methods as environmental DNA metabarcoding and bulk sample metabarcoding have been shown to provide an overview of species using specific TreMs (e.g., [80]).

Another way to improve knowledge on microhabitatdwelling species and specifically infer causal (functional) links would be to build controlled experimental designs involving artificial microhabitats. Most examples in the literature involve artificial cavities for birds [81, 82], but also for beetles [83], as well as other "easily" created microhabitats such as dendrotelms (water-filled holes [84]). Such experimental approaches provide a high level of evidence for species-TreM relationships, but their set-up is limited to TreMs that can be artificially created. In addition, an experimental approach involving a controlled set of TreMs is far more difficult than observational studies - if even possible - to set up, because the way TreMs are created is highly variable and not necessarily reproducible. In this sense, complementary approaches using both observational and experimental methods appear to be most promising. This works is ideally shared within large, international networks involving forest managers and ecologists working at different scales and with different perspectives [85].

\section{Ways to Validate Tree-Related Microhabitats as Biodiversity Indicators beyond Species Inventories}

Ecological sciences consider the correlation between indicator and indicandum as the main criterion of validation $[30,86]$. The use of TreMs as biodiversity indicators is no exception to this rule, and while so far relatively weak statistical correlations with different taxonomic groups have been documented, TreMs have been widely accepted by forest managers and the wider public as a tool to promote and assess integrative, conservation-minded forest management (see Table 1, [4, 5]). In addition, TreMs allow and accelerate communication between different stakeholders with various backgrounds [87.] which is important to reduce forest degradation as pointed out for deadwood [88] . In this sense, the interest of TreMs as a communication and education tool to forest biodiversity conservation is considerable and should be taken into account when assessing their usefulness as biodiversity indicator. This is in line with the criteria stated by the OECD that ideal biodiversity indicators should also be policy-relevant and accepted by the broad public [31•]. However, care must be taken that these aspects do not become more important than the relationship between indicator and indicandum. The remaining challenge is therefore to combine the evidence on ecological functions of TreMs with policy and management utility to fully assess the role of TreMs as biodiversity indicators.

\section{Conclusions}

TreMs are not the "silver bullet" indicator to quantify and predict species richness. Nevertheless, through their relationships with species from many taxonomic groups [41, 42], they have the potential to indicate habitat quality for a large section of forest-dwelling species, often better than other established indicators such as single focal species or red-list species [24, 27]. Combined with other types of direct or indirect (e.g., structural) biodiversity indicators, standard TreM inventories have the potential to capture a large proportion of forest biodiversity. 
TreM inventories are tailored at the stand scale, making them relevant and readily implemented in forest management. In addition, TreMs are broadly recognizable and intelligible to the broad public, and constitute tangible tools for communication of conservation efforts in forests. Therefore, TreMs already provide an applied and implemented approach for forest managers for the conservation of forest biodiversity through the retention of habitat trees. Further studies, especially outside Europe, are now needed to assess their indicative power and conservation relevance.

Supplementary Information The online version contains supplementary material available at https://doi.org/10.1007/s40725-020-00132-5.

Acknowledgments Open Access funding enabled and organized by Projekt DEAL. This study was funded by the German Research Foundation (DFG project GRK 2123). We are grateful to our field assistant David Grupp for the sampling of the mold cavities. Two anonymous reviewers provided very constructive comments that helped to improve this manuscript.

\section{Compliance with Ethical Standards}

Conflict of Interest There are no conflicts of interests to declare.

Human and Animal Rights This article does not contain any studies with human or animal subjects performed by any of the authors.

Open Access This article is licensed under a Creative Commons Attribution 4.0 International License, which permits use, sharing, adaptation, distribution and reproduction in any medium or format, as long as you give appropriate credit to the original author(s) and the source, provide a link to the Creative Commons licence, and indicate if changes were made. The images or other third party material in this article are included in the article's Creative Commons licence, unless indicated otherwise in a credit line to the material. If material is not included in the article's Creative Commons licence and your intended use is not permitted by statutory regulation or exceeds the permitted use, you will need to obtain permission directly from the copyright holder. To view a copy of this licence, visit http://creativecommons.org/licenses/by/4.0/.

\section{References}

Papers of particular interest, published recently, have been highlighted as:

- Of importance

•- Of major importance

1. Winter S, Möller GC. Microhabitats in lowland beech forests as monitoring tool for nature conservation. For Ecol Manag. 2008;255:1251-61.

2. Regnery B, Paillet Y, Couvet D, Kerbiriou C. Which factors influence the occurrence and density of tree microhabitats in Mediterranean oak forests? For Ecol Manag. 2013;295:118-25.

3. Vuidot A, Paillet Y, Archaux F, Gosselin F. Influence of tree characteristics and forest management on tree microhabitats. Biol Conserv. 2011;144:441-50.
4.• Larrieu L, Paillet Y, Winter S, Bütler R, Kraus D, Krumm F, et al. Tree related microhabitats in temperate and Mediterranean European forests: a hierarchical typology for inventory standardization. Ecol Indic. 2018;84:194-207 Main reference of the typology of TreMs.

5. Kraus D, Bütler R, Krumm, F., Lachat, T., Larrieu, L., Mergner, U., et al. Catalogue Tree-Microhabitats Reference-Field-List. Integrate+ Technical Paper [Internet]. 2016 [cited 2017 Jul 25]. Available from: http://www.integrateplus.org/uploads/images/ Mediacenter/Catalogue_Tree-Microhabitats_Reference-Field-List_ EN.pdf.

6. Gustafsson L, Baker SC, Bauhus J, Beese WJ, Brodie A, Kouki J, et al. Retention forestry to maintain multifunctional forests: a world perspective. BioScience. 2012;62:633-45.

7. Fedrowitz K, Koricheva J, Baker SC, Lindenmayer DB, Palik B, Rosenvald R, et al. REVIEW: Can retention forestry help conserve biodiversity? A meta-analysis. Baraloto C, editor. J Appl Ecol. 2014;51:1669-1679.

8. Kraus D, Krumm F, editors. Integrative approaches as an opportunity for the conservation of forest biodiversity. Bonn: European Forest Institute; 2013.

9. Bauhus J, Puettmann K, Messier C. Silviculture for old-growth attributes. For Ecol Manag. 2009;258:525-37.

10. Hilmers T, Friess N, Bässler C, Heurich M, Brandl R, Pretzsch H, et al. Biodiversity along temperate forest succession. Butt N, editor. Journal of Applied Ecology [Internet]. 2018 [cited 2018 Aug 3]; Available from: https://doi.org/10.1111/1365-2664.13238

11. Vandekerkhove K, Thomaes A, Jonsson B-G. Connectivity and fragmentation: island biogeography and metapopulation applied to oldgrowth-elements. In: Krumm F, Kraus D, editors. Integrative approaches as an opportunity for the conservation of forest biodiversity. Freiburg: European Forest Institute; 2013. p. 104-16.

12. Baguette M, Blanchet S, Legrand D, Stevens VM, Turlure C. Individual dispersal, landscape connectivity and ecological networks: dispersal, connectivity and networks. Biol Rev. 2013;88:310-26.

13.• Gustafsson L, Bauhus J, Asbeck T, Augustynczik ALD, Basile M, Frey J, et al. Retention as an integrated biodiversity conservation approach for continuous-cover forestry in Europe. AMBIO: J Human Environ. 2020;49:85-97 Addresses the importance of retention forestry based on TreMs as indicators in Central Europe.

14. Vítková L, Bače R, Kjučukov P, Svoboda M. Deadwood management in Central European forests: Key considerations for practical implementation. For Ecol Manag. 2018;429:394-405.

15. Bütler R, Lachat T, Larrieu L, Paillet Y. Habitat trees: key elements for forest biodiversity. In: Kraus D, Krumm F, editors. Integrative approaches as an opportunity for the conservation of forest biodiversity. Joensuu: European Forest Institute; 2013. p. 284.

16. Mölder A, Schmidt M, Plieninger T, Meyer P. Habitat-tree protection concepts over 200 years. Conservation Biology [Internet]. 2020 [cited 2020 Apr 15]; Available from: https://doi.org/10. 1111/cobi.13511

17. Asbeck T, Pyttel P, Frey J, Bauhus J. Predicting abundance and diversity of tree-related microhabitats in Central European montane forests from common forest attributes. For Ecol Manag. 2019;432: 400-8 Relevant source on drivers of TreM abundance.

18. Großmann J, Pyttel P, Bauhus J, Lecigne B, Messier C. The benefits of tree wounds: Microhabitat development in urban trees as affected by intensive tree maintenance. Urban For Urban Green. 2020;55:126817.

19. Cosyns H, Joa B, Mikoleit R, Krumm F, Schuck A, Winkel G, et al. Resolving the trade-off between production and biodiversity conservation in integrated forest management: comparing tree selection practices of foresters and conservationists. Biodivers Conserv [Internet]. 2020 [cited 2020 Sep 17]; Available from: https://doi. org/10.1007/s10531-020-02046-X 
20.• Gao T, Nielsen AB, Hedblom M. Reviewing the strength of evidence of biodiversity indicators for forest ecosystems in Europe. Ecol Indic. 2015;57:420-34 Overview of types of biodiversity indicators beyond TreMs.

21. Mace GM, Baillie JEM. The 2010 Biodiversity Indicators: Challenges for Science and Policy: The 2010 Biodiversity Indicators. Conserv Biol. 2007;21:1406-13.

22. Lassauce A, Paillet Y, Jactel H, Bouget C. Deadwood as a surrogate for forest biodiversity: Meta-analysis of correlations between deadwood volume and species richness of saproxylic organisms. Ecol Indic. 2011;11:1027-39.

23. Gregory R. Birds as biodiversity indicators for Europe. Significance. 2006;3:106-10.

24. Noss RF. Indicators for Monitoring Biodiversity: a Hierarchical Approach. Conserv Biol. 1990;4:355-64.

25. Marchetti M. Monitoring and Indicators of Forest Biodiversity in Europe - From Ideas to Operationality. :526.

26. Larsson T-B, Angelstam P, Balent G, Barbati A, Bijlsma R-J, Boncina A, et al. Biodiversity evaluation tools for European forests. Ecol Bull. 2001:1, 3-9, 11-7, 19-37, 39-139, 141-57, 159-221, 223-9, 231-7.

27. Magg N, Ballenthien E, Braunisch V. Faunal surrogates for forest species conservation: a systematic niche-based approach. Ecol Indic. 2019;102:65-75.

28. Storch F, Dormann CF, Bauhus J. Quantifying forest structural diversity based on large-scale inventory data: a new approach to support biodiversity monitoring. For Ecosyst. 2018;5:34.

29. Niemelä J. Biodiversity monitoring for decision-making. Ann Zool Fenn. 2000:307-17.

30. Niemeijer D, de Groot RS. A conceptual framework for selecting environmental indicator sets. Ecol Indic. 2008;8:14-25.

31. OECD International Expert Workshop. The-Post-2020Biodiversity-Framework-targets-indicators-and-measurability-implications. Paris: OECD; 2019. p. 27. Relevant and recent source for the concept of pressure-state-response framework.

32. Fahrig L. Rethinking patch size and isolation effects: the habitat amount hypothesis. J Biogeogr. 2013;40:1649-63.

33. European Forest Institute. Implementing criteria and indicators for sustainable forest management in Europe [Internet]. EFI; 2013. Available from: http://ci-sfm.org/uploads/Documents/2012/Virtual\%20Library/ Documents/CI-SFM-Project_Summary-ENG.pdf.

34. Levrel H, Kerbiriou C, Couvet D, Weber J. OECD pressure-stateresponse indicators for managing biodiversity: a realistic perspective for a French biosphere reserve. Biodivers Conserv. 2009;18: 1719-32.

35. Wolfslehner B, Vacik H. Evaluating sustainable forest management strategies with the Analytic Network Process in a Pressure-StateResponse framework. J Environ Manag. 2008;88:1-10.

36. Haberl H. Human appropriation of net primary production as an environmental indicator: implications for sustainable development. Ambio JSTOR. 1997:143-6.

37. Kahl T, Bauhus J. An index of forest management intensity based on assessment of harvested tree volume, tree species composition and dead wood origin. Nat Conserv. 2014;7:15-27.

38.• Kozák D, Mikoláš M, Svitok M, Bače R, Paillet Y, Larrieu L, et al. Profile of tree-related microhabitats in European primary beechdominated forests. For Ecol Manag. 2018;429:363-74 Important source to highlight the difference between managed and primary forests of TreMs.

39. Larrieu L, Cabanettes A, Gonin P, Lachat T, Paillet Y, Winter S, et al. Deadwood and tree microhabitat dynamics in unharvested temperate mountain mixed forests: A life-cycle approach to biodiversity monitoring. For Ecol Manag. 2014;334:163-73.

40. Larrieu L, Cabanettes A, Brin A, Bouget C, Deconchat M. Tree microhabitats at the stand scale in montane beech-fir forests: practical information for taxa conservation in forestry. Eur J For Res. 2014;133:355-67.
41.• Paillet Y, Archaux F, du Puy S, Bouget C, Boulanger V, Debaive N, et al. The indicator side of tree microhabitats: a multi-taxon approach based on bats, birds and saproxylic beetles. Firn J, editor. J Appl Ecol. 2018;55:2147-59 Relevant source to understand the relationship of taxonomic groups and TreMs.

42.• Basile M, Asbeck T, Jonker M, Knuff AK, Bauhus J, Braunisch V, et al. What do tree-related microhabitats tell us about the abundance of forest-dwelling bats, birds, and insects? J Environ Manag. 2020;264:110401 Relevant source to understand the relationship of taxonomic groups and TreMs.

43. Corona P, Chirici G, McRoberts RE, Winter S, Barbati A. Contribution of large-scale forest inventories to biodiversity assessment and monitoring. For Ecol Manag. 2011;262:2061-9.

44. Gustafsson L, Hannerz M, Koivula M, Shorohova E, VanhaMajamaa I, Weslien J. Research on retention forestry in Northern Europe. Ecol Process. 2020;9:3

45. Forest Europe. State of Europe's Forests 2015. Madrid: FOREST EUROPE Liaison Unit Madrid; 2015.

46. Ranius T, Snäll T, Nordén J. Importance of spatial configuration of deadwood habitats in species conservation. Conserv Biol. 2019; cobi:13387.

47. Grove SJ. Saproxylic Insect Ecology and the Sustainable Management of Forests. Annu Rev Ecol Syst. 2002;33:1-23.

48. Regnery B, Couvet D, Kubarek L, Julien J-F, Kerbiriou C. Tree microhabitats as indicators of bird and bat communities in Mediterranean forests. Ecol Indic. 2013;34:221-30.

49. Larrieu L, Cabanettes A. Species, live status, and diameter are important tree features for diversity and abundance of tree microhabitats in subnatural montane beech-fir forests 11 This article is one of a selection of papers from the International Symposium on Dynamics and Ecological Services of Deadwood in Forest Ecosystems. Can J For Res. 2012;42:1433-45.

50. Ouin A, Cabanettes A, Andrieu E, Deconchat M, Roume A, Vigan $\mathrm{M}$, et al. Comparison of tree microhabitat abundance and diversity in the edges and interior of small temperate woodlands. For Ecol Manag. 2015;340:31-9.

51. Paillet Y, Debaive N, Archaux F, Cateau E, Gilg O, Guilbert E. Nothing else matters? Tree diameter and living status have more effects than biogeoclimatic context on microhabitat number and occurrence: An analysis in French forest reserves. Bosela M, editor. PLoS One. 2019;14:e0216500 Relevant source on drivers of TreM abundance.

52. Jahed K, Farashiani S-T, Babanezhad C, et al. A comparison of the formation rates and composition of tree-related microhabitats in beech-dominated Primeval Carpathian and Hyrcanian forests. Forests. 2020;11:144 Relevant source on TreM research outside of Europe.

53. Martin M, Raymond P. Assessing tree-related microhabitat retention according to a harvest gradient using tree-defect surveys as proxies in Eastern Canadian mixedwood forests. For Chron. 2019;95:157-70 Relevant source on TreM research outside of Europe.

54. Michel AK, Winter S. Tree microhabitat structures as indicators of biodiversity in Douglas-fir forests of different stand ages and management histories in the Pacific Northwest, USA. Forest Ecol Manag. 2009;257:1453-64.

55. Asbeck T, Basile M, Stitt J, Bauhus J, Storch I, Vierling KT. Treerelated microhabitats are similar in mountain forests of Europe and North America and their occurrence may be explained by tree functional groups. Trees [Internet]. 2020 [cited 2020 Aug 5]; Available from: https://doi.org/10.1007/s00468-020-02017-3

56. Khanalizadeh A, Rad JE, Amiri GZ, Zare H, Rammer W, Lexer MJ. Assessing selected microhabitat types on living trees in Oriental beech (Fagus orientalis L.) dominated forests in Iran. Ann For Sci. 2020;77:91. 
57. Paillet Y, Archaux F, Boulanger V, Debaive N, Fuhr M, Gilg O, et al. Snags and large trees drive higher tree microhabitat densities in strict forest reserves. For Ecol Manag. 2017;389:176-86.

58. Großmann J, Schultze J, Bauhus J, Pyttel P. Predictors of Microhabitat Frequency and Diversity in Mixed Mountain Forests in South-Western Germany. Forests. 2018;9:104.

59. Courbaud B, Pupin C, Letort A, Cabanettes A, Larrieu L. Modelling the probability of microhabitat formation on trees using cross-sectional data. Börger L, editor. Methods Ecol Evol. 2017;8: 1347-59.

60. Puverel C, Abourachid A, Böhmer C, Leban J-M, Svoboda M, Paillet $\mathrm{Y}$. This is my spot: What are the characteristics of the trees excavated by the Black Woodpecker? A case study in two managed French forests. Forest Ecol Manag. 2019;453:117621.

61. Rozas V. Tree age estimates in Fagus sylvatica and Quercus robur: testing previous and improved methods. Plant Ecol. 2003;167:193212.

62. Hale SE, Gardiner BA, Wellpott A, Nicoll BC, Achim A. Wind loading of trees: influence of tree size and competition. Eur J Forest Res. 2012;15.

63. Bauhus J, Puettmann KJ, Kuehne C. Close-to-nature forest management in Europe: does it support complexity and adaptability of forest ecosystems? In: Messier C, Puettmann KJ, Coates KD, editors. Managing Forests as Complex Adaptive Systems: building resilience to the challenge of global change. Abington: Routledge; 2013. p. 187-213.

64. Brang P, Spathelf P, Larsen JB, Bauhus J. Bonc ina A, Chauvin C, et al. Suitability of close-to-nature silviculture for adapting temperate European forests to climate change. Forestry. 2014;87:492-503.

65. Asbeck T, Messier C, Bauhus J. Retention of tree-related microhabitats is more dependent on selection of habitat trees than their spatial distribution. Eur J Forest Res [Internet]. 2020 [cited 2020 Jul 7]; Available from: https://doi.org/10.1007/s10342-020-013036

66. Grosmann J, Pyttel P. Mikrohabitate und Baumdimension als Grundlage der Habitatbaum-Auswahl im Bergmischwald. Natur und Landschaft. 2019;94:531-41.

67. Fischer G, Laßnig-Wlad C, Marschnig M, Pfandl B, Plattner G, Rak C, et al. Naturschutzpraxisbuch - Naturschutzmaßnahmen als Beitrag zum Ökologischen Landschaftsmanagement [Internet]. Österreichische Bundesforste AG, editor. 2017 [cited 2020 May 5]. Available from: https://www.bundesforste.at/fileadmin/ naturraummanagement/Naturschutz/OEBf-Naturschutzpraxisbuch. pdf.

68. Staatsbetrieb Sachsenforst, editor. Dauerhafte Markierung von Biotopbaumgruppen in FFH-Gebieten. 2013.

69. Siitonen J. In: Stokland JN, Siitonen J, Jonsson BG, editors. Microhabitats. Biodiversity in Dead Wood. Cambridge: Cambridge University Press; 2012.

70. Bouget C, Larrieu L, Nusillard B, Parmain G. In search of the best local habitat drivers for saproxylic beetle diversity in temperate deciduous forests. Biodivers Conserv. 2013;22:2111-30.

71. Franc N, Götmark F, Økland B, Nordén B, Paltto H. Factors and scales potentially important for saproxylic beetles in temperate mixed oak forest. Biol Conserv. 2007;135:86-98.

72. Paillet Y, Coutadeur P, Vuidot A, Archaux F, Gosselin F. Strong observer effect on tree microhabitats inventories: a case study in a French lowland forest. Ecol Indic. 2015;49:14-23.

73. Hedgren O, Weslien J. Detecting Rare Species with Random or Subjective Sampling: a case study of Red-Listed Saproxylic Beetles in Boreal Sweden: Random or Subjective Sampling. Conserv Biol. 2008;22:212-5.

74. Rehush N, Abegg M, Waser LT, Brändli U-B. Identifying treerelated microhabitats in TLS point clouds Using Machine
Learning. Remote Sens. 2018;10:1735 Relevant source on TreM research based on remote-sensing techniques.

75. Santopuoli G, Febbraro MD, Maesano M, Balsi M, Marchetti M, Lasserre B. Machine Learning Algorithms to Predict Tree-Related Microhabitats using Airborne Laser Scanning; 2020. p. 19. Relevant source on TreM research based on remote-sensing techniques

76. - Frey J, Asbeck T, Bauhus J. Predicting Tree-Related Microhabitats by Multisensor Close-Range Remote Sensing Structural Parameters for the Selection of Retention Elements; 2020. p. 20. Relevant source on TreM research based on remote-sensing techniques.

77. Parmain G, Dufrêne M, Brin A, Bouget C. Influence of sampling effort on saproxylic beetle diversity assessment: implications for insect monitoring studies in European temperate forests: Saproxylic beetle monitoring: sampling effects. Agric For Entomol. 2013;15:135-45.

78. Gouix N, Brustel H. Emergence trap, a new method to survey Limoniscus violaceus (Coleoptera: Elateridae) from hollow trees. Biodivers Conserv. 2012;21:421-36.

79. Florentin J, Dutoit T, Verlinden O. Detection and identification of European woodpeckers with deep convolutional neural networks. Ecologic Inf. 2020;55:101023.

80. Garrick RC, Bouget C. Molecular Tools for Assessing Saproxylic Insect Diversity. In: Ulyshen MD, editor. Saproxylic Insects: Diversity, Ecology and Conservation [Internet]. Cham: Springer International Publishing; 2018. p. 849-84. Available from. https:// doi.org/10.1007/978-3-319-75937-1_25.

81. Cockle KL, Martin K, Drever MC. Supply of tree-holes limits nest density of cavity-nesting birds in primary and logged subtropical Atlantic forest. Biol Conserv. 2010;143:2851-7.

82. Lindenmayer DB, Welsh A, Donnelly C, Crane M, Michael D, Macgregor C, et al. Are nest boxes a viable alternative source of cavities for hollow-dependent animals? Long-term monitoring of nest box occupancy, pest use and attrition. Biol Conserv. 2009;142: 33-42.

83. Mestre L, Jansson N, Ranius T. Saproxylic biodiversity and decomposition rate decrease with small-scale isolation of tree hollows. Biol Conserv. 2018;227:226-32.

84. Gossner MM, Lade P, Rohland A, Sichardt N, Kahl T, Bauhus J, et al. Effects of management on aquatic tree-hole communities in temperate forests are mediated by detritus amount and water chemistry. Butler S, editor. J Anim Ecol. 2016;85:213-26.

85. Nilsen EB, Bowler DE, Linnell JDC. Exploratory and confirmatory research in the open science era. Fortin M, editor. J Appl Ecol. 2020;57:842-7.

86. Heink U, Kowarik I. What are indicators? On the definition of indicators in ecology and environmental planning. Ecol Indic. 2010;10:584-93.

87. Cosyns H, Kraus D, Krumm F, Schulz T, Pyttel P. Reconciling the tradeoff between economic and ecological objectives in habitat-tree selection: a comparison between students, foresters, and forestry trainers. For Sci. 2019;65:223-34 Relevant source on TreM research from a social science perspective.

88. Thorn S, Seibold S, Leverkus AB, Michler T, Müller J, Noss RF, et al. The living dead: acknowledging life after tree death to stop forest degradation. Front Ecol Environ. 2020;fee:2252.

89. Field R, Hawkins BA, Cornell HV, Currie DJ, Diniz-Filho JAF, Guégan J-F, et al. Spatial species-richness gradients across scales: a meta-analysis. J Biogeogr. 2009;36:132-47.

Publisher's Note Springer Nature remains neutral with regard to jurisdictional claims in published maps and institutional affiliations. 